\title{
The incidence of aspirin resistance in heart transplantation recipients
}

\author{
Tomasz Urbanowicz ${ }^{1}$, Anna Komosa ${ }^{2}$, Michał Michalak ${ }^{3}$, Tatiana Mularek ${ }^{2}$, Veronica Cassadei ${ }^{1}$, \\ Stefan Grajek², Marek Jemielity ${ }^{1}$ \\ ${ }^{1}$ Cardiac Surgery and Transplantology Department, Chair of Cardio-Thoracic Surgery, Poznan University of Medical Sciences, \\ Poznań, Poland \\ ${ }^{2}$ Cardiology Department, Poznan University of Medical Sciences, Poznań, Poland \\ ${ }^{3}$ Department of Computer Science and Statistics, Poznan University of Medical Sciences, Poznań, Poland
}

Kardiochirurgia i Torakochirurgia Polska 2017; 14 (2): 115-119

\begin{abstract}
Introduction: Coronary allograft vasculopathy can cause as many deaths as infections or rejection episodes within 3 years following heart transplantation.

Aim: To compare the aspirin resistance rate in an allograft heart transplantation population and in a control group by laboratory tests including the Aspirin-Resistant Patients Identification Test (ASPItest).

Material and methods: A total of 24 heart recipients (20 men and 4 women) at a mean age of $48 \pm 13$ years who underwent routine clinical follow-up were consecutively enrolled in group 1. The control group consisted of 24 patients (19 men and 5 women) at a mean age of $64 \pm 7$ years waiting for coronary artery bypass grafting in our department. All patients were treated with a standard dose of $75 \mathrm{mg}$ aspirin (ASA) daily.

Results: Aspirin resistance was evaluated by the Multiplate platelet function test. The ASPItest revealed a mean value of $27 \pm 22 \mathrm{U}$ in the transplant group. Results above $30 \mathrm{U}$ were obtained in 8 (34\%) patients, with a mean value of 50.3 $\pm 20.6 \mathrm{U}$, indicating aspirin resistance. In the control group ASPItest results above $30 \mathrm{U}$ were obtained in 5 (20\%) patients, with a mean value of $43.3 \pm 6.4 \mathrm{U}$.

Conclusions: There is a high incidence (34\% vs. $20 \%$, NS) of ASA resistance in heart transplantation recipients and in the general population, respectively.

Key words: heart transplantation, aspirin, ASPItest.
\end{abstract}

\section{Introduction}

Coronary allograft vasculopathy can cause as many deaths as infections or rejection episodes within 3 years following heart transplantation. Although changes in the coronary artery wall consist of diffuse artery lumen narrowing, routine use of aspirin is a standard preventive therapy.

Platelets are primary factors in clot formation and consequent acute coronary events. Thrombocytes are activat-

\section{Streszczenie}

Wstęp: Choroba naczyniowa graftu niesie ze sobą ryzyko zgonu porównywalne ze śmiertelnością z przyczyn infekcyjnych czy związanych z epizodami odrzucania w pierwszych 3 latach po operacji transplantacji serca.

Cel: Porównanie oporności na kwas acetylosalicylowy (ASA) u osób poddanych przeszczepowi serca i osób poddanych operacji bezpośredniej rewaskularyzacji mięśnia sercowego jako grupy kontrolnej. Do oceny oporności na ASA zastosowano ASPItest.

Materiał i metody: Grupę transplantacyjną stanowity 24 osoby (20 mężczyzn i 4 kobiety) w wieku średnio $48 \pm 13$ lat poddane procedurze przeszczepienia serca techniką klasyczną Lower-Shumway. Do grupy kontrolnej włączono 24 osoby (19 mężczyzn i 5 kobiet) w wieku $64 \pm 7$ lat poddanych operacji rewaskularyzacji bezpośredniej mięśnia sercowego. Wszyscy pacjenci otrzymywali standardową, dobową dawkę ASA 75 mg.

Wyniki: W badaniu ASPItest w grupie transplantacyjnej uzyskano średni wynik $27 \pm 22 \mathrm{U}$. Wyniki o wartości powyżej $30 \mathrm{U}$, wskazujące na oporność na ASA, otrzymano u 8 (34\%) pacjentów z wartością średnią 50,3 $\pm 20,6$ U. W grupie kontrolnej oporność na ASA potwierdzono u 5 (20\%) pacjentów z wartością średnią 43,3 „6,4 U.

Wnioski: Badanie potwierdziło wysoką oporność na ASA zarówno u pacjentów poddanych transplantacji serca, jak i poddanych operacji bezpośredniej rewaskularyzacji mięśnia sercowego.

Słowa kluczowe: transplantacja serca, kwas acetylosalicylowy, ASPItest.

ed by several agents including thromboxane A2, collagen, thrombin and adenosine-5-diphosphate (ADP). Aspirin (ASA) acts by irreversibly inactivating cyclooxygenase- 1 and thus decreasing the conversion of arachidonic acid to prostaglandin $\mathrm{H} 2$ and thereby the formation of platelet-derived thromboxane A2 (TXA2). Uncertainty remains regarding the incidence of the ASA resistance phenomenon among heart transplantation recipients.

Address for correspondence: Tomasz Urbanowicz MD, PhD, Cardiac Surgery and Transplantology Department, Chair of Cardio-Thoracic Surgery, Poznan University of Medical Sciences, 1/2 Długa St, 61-848 Poznań, Poland, phone: +48 605552 551, fax: +48 618549085 , e-mail: tk.urbanowicz@gmail.com

Received: 18.03.2017, accepted: 15.06.2017. 


\section{Aim}

The aim of the study was to compare the aspirin resistance rate in an allograft heart transplantation population and in a control group by laboratory tests including the Aspirin-Resistant Patients Identification Test (ASPItest).

\section{Material and methods}

A total of 24 patients (20 men and 4 women) at a mean age of $48 \pm 13$ years who underwent routine clinical follow-up after allograft heart transplantation were consecutively enrolled in the study. All patients were treated with a standard dose of 75 mg ASA daily. Patient compliance regarding aspirin intake was proven by family members' supervision.

The control group consisting of 24 patients (19 men and 5 women) with a mean age of $64 \pm 7$ years waiting for coronary artery bypass grafting in our department was enrolled in the study. All patients in group 2 were treated with a standard dose of $75 \mathrm{mg}$ ASA daily. The diagnosis of dyslipidemia was related to basic results. Detailed demographic and clinical information is presented in Table I.

The aim of the study was to evaluate the aspirin resistance rate in both groups by laboratory tests including the Aspirin-Sensitive Patients Identification Test (ASPItest).

Platelet aggregation tests was performed on Multiplate platelet function analyzer on whole blood samples (Roche Diagnostic, Germany). The method is based on measurements of electric resistance that occur during platelets' ad-

Tab. I. Clinical and demographic data

\begin{tabular}{|c|c|c|c|}
\hline Parameter & $\begin{array}{l}\text { Transplant } \\
\text { group } \\
(n=24)\end{array}$ & $\begin{array}{l}\text { Control } \\
\text { group } \\
(n=24)\end{array}$ & $P$-value \\
\hline Age [years] & $48 \pm 13$ & $64 \pm 7$ & $<0.05$ \\
\hline Gender (M/F) & $\begin{array}{c}19(80 \%) \\
5(20 \%)\end{array}$ & $\begin{array}{c}19(80 \%) \\
5(20 \%)\end{array}$ & \\
\hline \multicolumn{4}{|l|}{ Transplantation indications: } \\
\hline Ischemic cardiomyopathy & $10(42 \%)$ & & \\
\hline Dilated cardiomyopathy & $12(50 \%)$ & & \\
\hline Hypertrophic cardiomyopathy & $2(8 \%)$ & & \\
\hline \multicolumn{4}{|l|}{$\begin{array}{l}\text { Coronary bypass grafting } \\
\text { indications: }\end{array}$} \\
\hline Left main stenosis & & $8(33 \%)$ & \\
\hline 2-vessel disease & & $12(50 \%)$ & \\
\hline 3-vessel disease & & $4(17 \%)$ & \\
\hline \multicolumn{4}{|l|}{ Concomitant diseases: } \\
\hline Arterial hypertension & $10(42 \%)$ & $15(62 \%)$ & NS \\
\hline Kidney dysfunction & $7(29 \%)$ & $7(29 \%)$ & NS \\
\hline Diabetes mellitus & $8(33 \%)$ & $8(33 \%)$ & NS \\
\hline Peripheral artery disease & $2(8 \%)$ & $2(8 \%)$ & NS \\
\hline $\begin{array}{l}\text { Chronic obstructive pulmonary } \\
\text { disease }\end{array}$ & $1(4 \%)$ & $2(8 \%)$ & NS \\
\hline Dyslipidemia & $3(12 \%)$ & $11(46 \%)$ & $<0.05$ \\
\hline Stroke in medical history & $1(4 \%)$ & $2(8 \%)$ & NS \\
\hline
\end{tabular}

hesion and aggregation to two electrodes, which is recorded for 6 consecutive minutes [1]. The results are presented as area under the curve (AUC). Values of ASPItest below $30 \mathrm{U}$ are related to strong inhibition of cyclooxygenase-1 enzyme (COX-1) on the surface of the platelets, which was an indicator of aspirin sensitivity [2].

The laboratory tests including whole blood count and kidney and liver functions tests were evaluated.

The indication for heart transplantation was end stage heart failure due to ischemic $(n=10)$, dilated idiopathic $(n=12)$ or hypertrophic $(n=2)$ cardiomyopathy. The mean time since transplantation was $48 \pm 28$ months. Patients were treated with two different immunosuppressive regimens including tacrolimus and cyclosporine (both calcineurin inhibitor-based protocols) which are presented in detail in Table I. All patients were clinically stable in NYHA class I (22 patients) and II (2 patients). When the diagnostic measurements were performed none of the patients were suffering either from a rejection episode or infection.

The control group consisted of patients awaiting a coronary artery bypass grafting procedure. The indication for surgical intervention was left main disease in 8 (33\%) patients, two-vessel disease including proximal left descending artery disease in 12 (50\%) patients and three-vessel disease in $4(17 \%)$ more patients.

Laboratory tests were performed consisting of the standard coagulation test and liver and kidney tests followed by complete blood count. The coagulation test included activated partial prothrombin time (APTT), international ratio (INR) and the ASPItest. The laboratory kidney function test consisted of serum creatinine, and liver tests included serum albumin concentration, overall protein serum concentration, aspartate and alanine transaminases (AST and ALT). Complete blood count included white cell serum concentration, hemoglobin and thrombocyte concentrations.

\section{Statistical analysis}

Interval data were presented as means and standard deviations. Nominal data were presented as percentages. To compare clinical parameters between analyzed groups - control vs. heart transplantation recipients - Student's $t$ test (parametric) was used when data followed a normal distribution (Shapiro-Wilk test). If data did not follow a normal distribution the Mann-Whitney rank sum test (nonparametric) was used. The dependence between groups and nominal data was analyzed using Fisher's exact test.

The percentages of sensitivity and resistance among control patients vs. heart transplantation recipients was compared with the test for proportions.

Statistical analyses were performed with Statistica 10 (StatSoft Inc., Poland). All tests were considered significant at a $p$-value of less than 0.05 .

\section{Results}

The platelet function test (ASPItest) revealed a mean value of $27 \pm 22 U$ in the transplant group. In the heart re- 
cipient group ASPItest values below $30 \mathrm{U}$ were found in $16(66 \%)$ patients with a mean value of $13.8 \pm 6.1 \mathrm{U}$. ASPItest results above $30 \mathrm{U}$ were obtained in 8 (34\%) patients, with a mean value of $50.3 \pm 20.6 \mathrm{U}$.

There were 5 (50\%) of 10 patients diagnosed with ASA resistance in the ischemic cardiomyopathy subgroup who were referred for heart transplantation.

The comparison of ASA resistance and sensitivity in both groups is presented in Figure 1.

The platelet function test (ASPItest) revealed a mean value of $24 \pm 13 \mathrm{U}$ in the control group. In the control group ASPItest values below $30 \mathrm{U}$ were found in 19 (80\%) patients with a mean value of $19.6 \pm 9.3 \mathrm{U}$. The results obtained in aspirin-sensitive subgroups were statistically not significant in the transplant versus control group $(13.8 \pm 6.1 \mathrm{U}$ vs. $19.6 \pm 9.3 \mathrm{U}, \mathrm{NS})$. ASPItest results above $30 \mathrm{U}$ were obtained in $5(20 \%)$ more patients, with a mean value of $43.3 \pm 6.4 \mathrm{U}$.

There was no difference in other coagulation parameters, e.g. prothrombin time $(97.7 \pm 19.2 \mathrm{~s}$ vs. $101 \pm 9.6 \mathrm{~s}$ in group 1 and 2, respectively (NS)). The mean value of INR ratio was $1.2 \pm 0.8$ vs. $1 \pm 0.1$ in group 1 and 2 , respectively (NS). There was no statistically significant difference in liver function test including aminotransferase - ALT (29.1 \pm 10.9 IU/I vs. $32 \pm 15$ IU/I in group 1 and 2, respectively (NS)) and aminophosphatase - AST (25.5 \pm 8.7 IU/I vs. $29.2 \pm 10.1 \mathrm{IU} / \mathrm{I}$ in group 1 and 2, respectively (NS)). Serum protein concentration (76.6 $\pm 5.4 \mathrm{~g} / \mathrm{l}$ vs. $76.2 \pm 3.3 \mathrm{~g} / \mathrm{l}$; NS) and serum albumin ( $43.5 \pm 3.1 \mathrm{~g} / \mathrm{l}$ vs. $45 \pm 1.7 \mathrm{~g} / \mathrm{l}$; NS) were not different between groups. Kidney function estimated by serum creatinine concentration was not statistically significantly different between groups (147 $\pm 54 \mu \mathrm{mol} / \mathrm{l}$ vs. $138.2 \pm 47$ $\mu \mathrm{mol} / \mathrm{l}$ in group 1 and 2 , respectively). Laboratory results are presented in Table II.

There was no difference in whole blood count between groups; white blood count was $6.4 \pm 1.3 \times 1000 / \mathrm{mm}^{3}$ vs. $6.5 \pm 1.4 \times 1000 / \mathrm{mm}^{3}$ (NS) and hemoglobin serum concentration $8.4 \pm 1.1 \mathrm{mmol} / \mathrm{l}$ vs. $8 \pm 0.7 \mathrm{mmol} / \mathrm{l}$ in group 1 and 2 , respectively (NS). The serum thrombocyte concentration was $185 \pm 44 \times 1000 / \mathrm{mm}^{3}$ and $189 \pm 63 \times 1000 / \mathrm{mm}^{3}$ in group 1 and 2, respectively.

Patients were under two different immunosuppressive protocols but all based on calcineurin inhibitor therapy. There were 20 (83.3\%) patients treated with tacrolimus with a measured mean serum concentration of $12.5 \pm 3 \mathrm{mg} / \mathrm{dl}$ and $4(16.7 \%)$ on cyclosporine therapy with a mean serum concentration of $90 \pm 20.2 \mathrm{mg} / \mathrm{dl}$. Mean serum mycophenolate mofetil concentration was $2.45 \pm 1.9 \mu \mathrm{g} / \mathrm{ml}$.

\section{Discussion}

Although heart transplantation is the optimal treatment option for patients suffering from heart failure, prevalence is estimated to be as high as $8 \%$ in the population, and its long-term complications limit the results $[3,4]$. Coronary allograft vasculopathy can cause as many deaths as infections or rejection episodes within 3 years following heart transplantation [5]. Accelerated coronary artery disease and myocardial infarction complicate up to $50 \%$ of patients

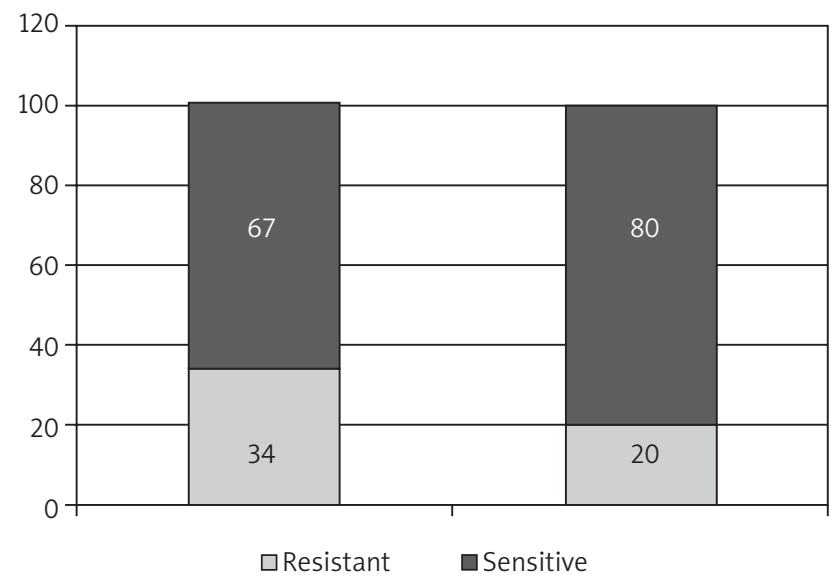

Fig. 1. Aspirin sensitivity and resistance in each group

within 5 years following transplantation [6]. Hyperlipidemia and hypertension are not among main risk factors of ischemic disease in heart transplantation recipients [7]. Although cardiac allograft vasculopathy is one of the major causes of death among heart transplant recipients, the pathogenesis of this cardiovascular complication, involving chronic inflammatory processes, is not fully clarified [8].

Platelets play an important role in thrombus formation but several studies point to their involvement in inflammatory processes [9-13]. ASA is integral to the secondary

Tab. II. ASPItest and coagulation test results in transplant group (group 1), and control (group 2)

$\begin{array}{llll}\text { Parameter } & \begin{array}{lll}\text { Group 1 } \\ (n=24)\end{array} & \begin{array}{l}\text { Group 2 } \\ (n=24)\end{array} & \text { P-value } \\ & & & \end{array}$

Laboratory coagulation tests:

\begin{tabular}{lccc}
\hline APTT $(\mathrm{s})$ & $97.7 \pm 19.2$ & $101 \pm 9.6$ & NS \\
\hline INR & $1.2 \pm 0.9$ & $1 \pm 0.1$ & NS \\
\hline Mean ASPI value [U] & $27 \pm 22$ & $24.3 \pm 13$ & $<0.05$ \\
\hline
\end{tabular}

\begin{tabular}{lccc} 
Mean ASPI value [U] & $27 \pm 22$ & $24.3 \pm 13$ & $<0.05$ \\
\hline Aspirin: & & & \\
\hline Sensitivity: & $16(67 \%)$ & $12(80 \%)$ & \\
\hline Mean ASPI value [U] & $13.8 \pm 6.1$ & $19.6 \pm 9.3$ & $<0.05$ \\
\hline Resistance: & $8(33 \%)$ & $3(20 \%)$ & \\
\hline Mean ASPI value [U] & $50.2 \pm 20.6$ & $43.3 \pm 6.4$ & $<0.05$
\end{tabular}

Liver function tests:

\begin{tabular}{lccc}
\hline ALT [IU/I] & $29.1 \pm 10.9$ & $32.1 \pm 15$ & NS \\
\hline AST [IU/l] & $25.5 \pm 8.7$ & $29.2 \pm 10.1$ & NS \\
\hline Whole protein [g/dl] & $76.6 \pm 5.4$ & $76.2 \pm 3.3$ & NS \\
\hline Albumin [g/dl] & $43.5 \pm 3.2$ & $45 \pm 1.7$ & NS \\
\hline
\end{tabular}

Kidney function test:

\begin{tabular}{llll}
\hline Creatinine $[\mu \mathrm{mol} / \mathrm{l}]$ & $147 \pm 54$ & $138 \pm 47$ & NS \\
\hline
\end{tabular}

Complete blood count:

\begin{tabular}{lccc}
\hline White cells $\left[\times 10^{9} / \mathrm{dl}\right]$ & $6.43 \pm 1.3$ & $6.5 \pm 1.4$ & NS \\
\hline Hemoglobin $[\mathrm{mmol} / \mathrm{dl}]$ & $8.4 \pm 1.1$ & $8 \pm 0.7$ & NS \\
\hline Thrombocytes $\left[\times 10^{3} / \mathrm{dl}\right]$ & $185 \pm 63$ & $189 \pm 63$ & NS \\
\hline
\end{tabular}


prevention of cardiovascular disease and acts to impair the development of platelet-mediated atherothromboembolic events by irreversible inhibition of platelet cyclooxygenase-1 (COX-1). Inhibition of this enzyme prevents the synthesis of the potent pro-aggregatory prostanoid thromboxane $A_{2}$ [14-16]. Thrombi at different stages of organization were also found in histological examinations of transplanted hearts [17-19].

A large number of patients continue to experience atherothromboembolic events despite aspirin therapy, socalled 'aspirin treatment failure', and this is multifactorial in etiology [20].

Three types of ASA resistance are defined. Type I, called pharmacokinetic resistance, occurs when aspirin fails to inhibit COX-1 despite its adequate dosing. It is explained by aspirin malabsorption or genetic polymorphisms in COX-1. In type II, named pharmacodynamic resistance, continued thromboxane production occurs despite adequate COX-1 inhibition. Type III is ASA pseudoresistance that is related to inadequate drug intake mainly due to noncompliance.

There are several laboratory options for measuring platelet function in patients receiving aspirin therapy. The Aspirin-Sensitive Patients Identification Test (ASPItest) is a Multiplate electrode aggregometry (MEA) test. It is based on a development of Cardinal and Flower's 1979 impedance aggregometry method [21]. Values < $30 \mathrm{U}$ indicate strong COX-1 inhibition by aspirin. This level is considered a cut-off for strong inhibition of COX-1 by aspirin [22]. The ASPItest is confirmed to be a reliable tool in aspirin resistance diagnosis [23-26]. A high frequency (34\%) of aspirin resistance in heart transplantation recipients was found in the present study.

The increased platelet aggregation in heart transplantation recipients has already been described in previous human and animal studies [27-29]. The enhanced platelet response to ADP was reported in patients following heart transplantation. It is associated with changes in platelet fatty acids and a high cholesterol-to-phospholipid ratio, which is associated not only with decreased membrane fluidity but also platelet hyperreactivity [30-32]. There was no statistically significant difference in ASA resistance between the transplant and control group. Although there was a significant age difference between groups, we found no correlation between ASA resistance and age in multivariate analysis. The study revealed high occurrence of aspirin resistance in each population. The only difference noted in the present study concerned the results obtained in aspirin sensitive subgroups (13.8 $\pm 6.1 \mathrm{U}$ vs. $19.6 \pm 9.3 \mathrm{U}$, $p<0.05)$.

Calcineurin inhibitor based triple-drug immunosuppression therapy, despite reducing the number of acute graft episodes, does not reduce the incidence of post-transplant coronary disease. It is partially explained by the calcineurin inhibitor influence on platelet lipid metabolism and aggregability [33]. High incidence of ASA resistance point to the underdiagnosed problem in the heart transplant population.
We believe that routine ASA resistance evaluation in both heart transplant and coronary artery bypass grafting groups should be routine clinical practice. It may be very helpful in pointing out those who should be treated with other antiplatelets drugs. The heart transplant recipients who are resistant to ASA should have their immunosuppressive regimens modified so as to reduce the risk of graft vasculopathy. They should probably be treated with higher doses of immunosuppressive drugs to slow or prevent chronic humoral rejection in future.

\section{Conclusions}

There is a high incidence of ASA resistance in heart transplantation recipients and the general population that indicates the need for routine diagnosis in patients referred for aspirin therapy.

\section{Disclosure}

Authors report no conflict of interest.

\section{References}

1. Woźniak S, Woźniak K, Hryniewiecki T, Kruk M, Różański J, Kuśmierczyk M. The predictive value of multiple eletrode platelet aggregometry for postoperative bleeding complications in patients undergoing coronary artery bypass graft surgery. Kardiochir Torakochir Pol 2016; 13: 3-9.

2. von Pape KW, Dzijan-Horn M, Bohner J, Spannagl M, Weisser H, Calatzis A. Control of aspirin effect in chronic cardiovascular patients using two whole blood paltelet function assay. PFA-100 and Multiplate. Hamostaseologie 2007; 27: 155-160.

3. Urbanowicz T, Straburzyńska-Migaj E, Katyńska I, Araszkiewicz A, Oko-Sarnowska Z, Grajek S, Jemielity M. Sustained Improvement of clinical status and pulmonary hypertension in patients with severe heart failure treated with sildenafil. Ann Transplant 2014; 19: 325-330.

4. Urbanowicz T, Baszyńska-Wachowiak H, Ligowski M, Straburzyńska-Migaj E, Misterski M, Jemielity M. Comparison of conventional tacrolimus versus prolong release formula as initial therapy in heart transplantation. Ann Transplant 2014; 19: 295-299.

5. Hertz MI, Taylor DO, Trulock EP, Boucek MM, Mohacsi PJ, Edwards LB, Keck BM. The registry of the International Society for Heart and Lung Transplantation: nineteenth official report - 2002. J Heart Lung Transplant 2002; 21: 950-970.

6. Gao SZ, Schroeder JS, Alderman EL, Hunt SA, Valantine HA. Prevalence of accelerated coronary artery disease in heart transplant survivors. Circulation 1989; 80 (Suppl III): 100-105.

7. Billingham ME. Cardia transplant atherosclerosis. Transplant Proc 1987; 19 (4 Suppl. 5): 19-25.

8. Hognestad A, Michelsen A, Brosstad F, Damas JK, Holm T, Simonsen S, Kjekshus JK, Aukrust P, Andreassen AK. Platelet activation in heart transplant recipients. Clin Transplant 2004; 18: 142-147.

9. Lefer AM. Platelets: unindicted coconspirators in inflammatory tissue injury. Circ Res 2000; 87: 1077-1078.

10. Stokes KY, Granger DN. Platelets: a critical link between inflammation and microvascular dysfunction. J Physiol 2012; 590: 1023-1034.

11. Page CP. Platelets as inflammatory cells. Immunopharmacology 1989; 17: 51-59.

12. Ghoshal K, Sacharymetria M. Overview of platelet physiology: its hemostatic and nonhemostatic role in disease pathogenesis. Sci World J 2014; 2014: 781857.

13. Michelson AD. Flow cytometry: a clinical test of platelet function. Blood 1996; 87: 4925-4936.

14. Gawaz M, Neumann FJ, Dickfeld T, Koch W, Laugwitz KL, Adelsberger H, Langenbrink K, Page S, Neumeier D, Schömig A, Brand K. Activated platelets induce monocyte chemotactic protein-1 secretion and surface expression of intercellular adhesion molecule-1 on endothelial cells. Circulation 1998; 98: 1164-1171. 
15. Mercer JR. Mitochondrial bioenergetics and therapeutic intervention in cardiovascular disease. Pharmacol Ther 2014; 141: 13-20.

16. Henn V, Slupsky JR, Gräfe M, Anagnostopoulos I, Förster R, Müller-Berghaus G, Kroczek RA. CD40 ligand on activated platelets triggers an inflammatory reaction of endothelial cells. Nature 1998; 391: 591-594.

17. Uretsky BF, Murali S, Reddy PS, Rabin B, Lee A, Griffith BP, Hardesty RL, Trento A, Bahnson HT. Development of coronary artery disease in cardiac transplant patients receiving immunosuppressive therapy with cyclosporine and prednisone. Circulation 1987; 76: 827-834.

18. Hess ML, Hastillo A, Mohanakumar T, Cowley MJ, Vetrovac G, Szentpetery S, Wolfgang TC, Lower RR. Accelerated atherosclerosis in cardiac transplantation: role of cytotoxic B-cell antibodies and hyperlipidemia. Circulation 1983; 68 (Suppl II): 94-101.

19. de Lorgeril M, Dureau G, Boissonnat P, Guidollet J, Juhan-Vague I, Bizollon C Renaud S. Platelet function and composition in heart transplant recipients compared with nontransplanted coronary patients. Arterioscler Thromb Vasc Biol 1992; 12: 222-230.

20. Floyd CN, Ferro A. The mechanisms of aspirin resistance. Pharmacol The 2014; 141: 69-78.

21. Al-Azzam SI, Alzoubi KH, Khabour O, Alowidi A, Tawalbeh D. The prevalence and factors associated with aspirin resistance in patients premedicated with aspirin. Acta Cardiol 2012; 67: 445-448.

22. von Pape KW. Control of aspirin effect in chronic cardiovascular patients using two whole blood platelet function assays. PFA-100 and Multiplate. Hamostaseologie 2007; 27: 155-160.

23. Jámbor C, Weber CF, Gerhardt K, Dietrich W, Spannagl M, Heindl B, Zwissler B. Whole blood multiple electrode aggregometry is a reliable point-of-care test of aspirin-induced platelet dysfunction. Anesth Analg 2009; 109: 25-31.

24. Petricevic M, Biocina B, Konosic S, Kopjar T, Kunac N, Gasparovic H. As sessment of platelet function by whole blood impedance aggregometry in coronary artery bypass grafting patients on acetylsalicylic acid treatment may prompt a switch to dual antiplatelet therapy. Heart Vessels 2013; 28: 57-65.

25. Meves SH, Neubauer H, Overbeck U, Endres HG. Is there an ideal way to initiate antiplatelet therapy with aspirin? A crossover study on healthy volun teers evaluating different dosing schemes with whole blood aggregometry. BMC Res Notes 2011; 4: 106

26. Stafford $M$, Weitzel N. Point of care testing in cardiac surgery: diagnostic modalities to assess coagulation and platelet function. Drug Develop Res 2013; 74: 418-427.

27. Modjeski KL, Morrell CN. Small cells, big effects: the role of platelets in transplant vasculopathy. J Thromb Thrombolysis 2014; 37: 17-23.

28. Vanrenterghem Y, Lerut T, Roels L, Gruwez J, Michielsen P. Thromboembolic complications and haemostatic changes in cyclosporine-treated cadaveric kidney allograft recipients. Lancet 1985; 4: 999-1002.

29. Frampton G, Parbtani A, Marchesi D, Duffus P, Livio M, Remuzzi G, Cameron S. In vivo platelet activation with in vitro hyperaggregability to arachidonic acid in renal allograft recipients. Kidney Int 1983; 23: 506-513.

30. Sabine JR. Membrane homeostasis: is there an optimum level of membrane cholesterol? Biosci Rep 1983; 3: 337-344.

31. Hajjawi OS. Human red blood cells-1. Am J Life Sci 2013; 1: 195-214.

32. Nurden AT. Platelets, inflammation and tissue regeneration. Thromb Haemost 2011; 105 Suppl. 1: S13-S33.

33. Olivari MT, Homans DC, Wilson RF, Kubo SH, Ring WS. Coronary artery disease in cardiac transplant patients receiving triple-drug immunosuppressive therapy. Circulation 1989; 80 (Suppl III): 111-115. 